\title{
Pharmaceutical Studies on "Dang-Gui" in Korean Journals
}

\author{
Jongmin Ahn ${ }^{1,2}$, Mi-Jeong Ahn ${ }^{3}$, Young-Won Chin ${ }^{1}$, and Jinwoong Kim ${ }^{1, *}$ \\ ${ }^{I}$ College of Pharmacy and Research Institute of Pharmaceutical Sciences, Seoul National University, \\ Seoul 08826, Republic of Korea \\ ${ }^{2}$ National Center for Natural Products Research, Research Institute of Pharmaceutical Sciences, School of Pharmacy, \\ The University of Mississippi, University, MS 38677, USA \\ ${ }^{3}$ College of Pharmacy and Research Institute of Pharmaceutical Sciences, Gyeongsang National University, \\ Jinju 52828, Republic of Korea
}

\begin{abstract}
A crude drug "Dang-Gui", belonging to the genus Angelica, has been used as a traditional herbal medicine in Asia. Various studies have investigated the chemical components and pharmacological activities of Dang-Gui worldwide. However, domestic research results published in Korean are undervalued in international academia due to language barriers. Therefore, it is necessary to summarize the domestic research findings systematically for greater accessibility. This review focuses on the results published in four Korean pharmaceutical journals between 1970 and 2018, which detail the botanical, phytochemical, and pharmacological properties of three Angelica species (A. gigas, A. sinensis, and A. acutiloba) used as "Dang-Gui" in Korea, China, and Japan.
\end{abstract}

Keywords - Dang-Gui, Angelica gigas, Angelica sinensis, Angelica acutiloba, phytochemical, pharmacological, Korean journal

\section{Introduction}

"Dang-Gui" refers to the roots of medicinal plants belonging to the genus Angelica (Umbelliferae) that have been widely used as traditional medicine throughout Korea, China, and Japan. Korean, Chinese, and Japanese Pharmacopoeia define Dang-Gui as a different botanical origin: Angelica gigas Nakai, Angelica sinensis (Oliv.) Diels and Angelica acutiloba Kitagawa, respectively. ${ }^{1-3}$ For example, in Korean Pharmacopoeia the roots of $A$. gigas are "Dang-Gui", while the roots of A. acutiloba are "Il-Dang-Gui", meaning Japanese Dang-Gui.

Multiple pharmaceutical studies on Dang-Gui have been conducted both domestically and worldwide. Between 1970 and 2018, approximately 400, 200, and 3600 international papers have been published about $A$. gigas, A. acutiloba, and $A$. sinensis, respectively. Unfortunately, due to language barriers, papers published in Korean journals are often disregarded. For this reason, domestic research results are underestimated in international academia.

\footnotetext{
*Author for correspondence

Jinwoong Kim, College of Pharmacy and Research Institute of Pharmaceutical Sciences, Seoul National University, Seoul 08826, Republic of Korea

Tel: +82-2-880-7853; E-mail: jwkim@snu.ac.kr
}

Therefore, it is necessary to summarize domestic research results systematically for international accessibility. This work summarizes domestic research performed on three Angelica species used as Dang-Gui in Korea, China, and Japan. This review is limited to studies published between 1970 and 2018 in four Korean pharmaceutical journals (Korean Journal of Pharmacognosy, Yakhak Hoeji, Natural Product Sciences, and Archives of Pharmacal Research), of which the former two are written in Korean. The number of relevant articles in these journals is 13,5 , 6 and 9, respectively, and their collective findings are summarized herein.

\section{Inner morphological studies}

Comparative histological studies were carried out to clarify the origins of the three Angelica species. ${ }^{4,5}$ According to these studies, the three species are distinguished by the shape of the cork cortex, resin duct and xylem fiber, frequency and size of secretory cells, and the size of vessels. For example, $A$. sinensis can be recognized by the number of cork cells in the cork layer (4 - 7), which is the greatest among the three species. A. acutiloba has the largest resin duct diameter $(200-300 \mu \mathrm{m})$ and the lowest duct frequency. In comparison, A. gigas displays the 
smallest duct diameter $(20-60 \mu \mathrm{m})$ and the highest frequency among the three species. The diameter and frequency of the resin duct in $A$. sinensis are slightly larger than those of A. gigas. A. acutiloba also shows the greatest number $(25-40)$ of secretory cells surrounding the resin duct, followed by $A$. sinensis and A. gigas $(5-8)$. The xylem fibers of $A$. gigas are the most well-developed among the three species, while those of $A$. acutiloba and A. sinensis are similar to each other. A. acutiloba has the smallest vessel diameter $(15-40 \mu \mathrm{m})$, while the vessel diameters of $A$. gigas and $A$. sinensis are similar (20 - 80 $\mu \mathrm{m}$ and $20-90 \mu \mathrm{m}$, respectively).<smiles>[R]c1c2ccoc2c([R])c2oc(=O)ccc12</smiles>

$1 \mathrm{R}_{1}=\mathrm{OCH}_{3}, \mathrm{R}_{2}=\mathrm{H}$ $3 \mathrm{R}_{1}=\mathrm{OCH}_{2} \mathrm{CH}=\mathrm{C}\left(\mathrm{CH}_{3}\right)_{2}$ $8 \mathrm{R}_{1}=\mathrm{OH}, \mathrm{R}_{2}=\mathrm{OCH}_{3}$<smiles>[R]C1c2cc3ccc(=O)oc3cc2OC(C)(C)C1[R]</smiles>

$9 \mathrm{R}_{1}=\mathrm{O}$-Sen, $\mathrm{R}_{2}=\mathrm{O}$-Sen

$10 \mathrm{R}_{1}=\mathrm{H}, \mathrm{R}_{2}=\mathrm{O}-\mathrm{Sen}$

$11 \mathrm{R}_{1}=\mathrm{H}, \mathrm{R}_{2}=\mathrm{OH}$

$12 \mathrm{R}_{1}=\mathrm{H}, \mathrm{R}_{2}=\mathrm{O}$-Ang

$13 \mathrm{R}_{1}=\mathrm{H}, \mathrm{R}_{2}=\mathrm{O}-(2 R, 3 R)$-epoxyangeloyl

$14 \mathrm{R}_{1}=\mathrm{H}, \mathrm{R}_{2}=\mathrm{O}$ - $(2 S, 3 S)$-epoxyangeloyl

$15 \mathrm{R}_{1}=\mathrm{H}, \mathrm{R}_{2}=\mathrm{O}-4$-hydroxysenecioyl

$16 \mathrm{R}_{1}=\mathrm{H}, \mathrm{R}_{2}=\mathrm{O}-4$-hydroxytigloyl

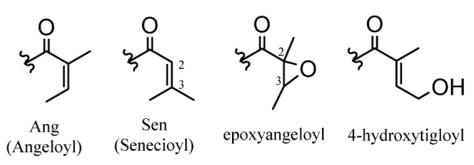<smiles>CC1(C)C=Cc2cc3ccc(=O)oc3cc2O1</smiles>

17<smiles>[R20]Oc1ccc(-c2oc3cc([R20])cc(O)c3c(=O)c2[R])cc1[R]</smiles>

$29 \mathrm{R}_{1}=\mathrm{OH}, \mathrm{R}_{2}=\mathrm{H}, \mathrm{R}_{3}=\mathrm{O}-\mathrm{Ara}, \mathrm{R}_{4}=\mathrm{H}$

$30 \mathrm{R}_{1}=\mathrm{OH}, \mathrm{R}_{2}=\mathrm{CH}_{3}, \mathrm{R}_{3}=\mathrm{H}, \mathrm{R}_{4}=\mathrm{Rha}\left(1^{\prime \prime}-6^{\prime}\right) \mathrm{Glc}$

$31 \mathrm{R}_{1}=\mathrm{OH}, \mathrm{R}_{2}=\mathrm{H}, \mathrm{R}_{3}=\mathrm{O}-\mathrm{Glc}, \mathrm{R}_{4}=\mathrm{H}$

$32 \mathrm{R}_{1}=\mathrm{H}, \mathrm{R}_{2}=\mathrm{H}, \mathrm{R}_{3}=\mathrm{OH}, \mathrm{R}_{4}=\mathrm{H}$

$33 \mathrm{R}_{1}=\mathrm{OH}, \mathrm{R}_{2}=\mathrm{H}, \mathrm{R}_{3}=\mathrm{H}, \mathrm{R}_{4}=\mathrm{H}$

$34 \mathrm{R}_{1}=\mathrm{OH}, \mathrm{R}_{2}=\mathrm{H}, \mathrm{R}_{3}=\mathrm{H}, \mathrm{R}_{4}=\mathrm{Glc}$

$35 \mathrm{R}_{1}=\mathrm{OH}, \mathrm{R}_{2}=\mathrm{H}, \mathrm{R}_{3}=\mathrm{OH}, \mathrm{R}_{4}=\mathrm{H}$<smiles>O=c1ccc2ccc3c(c2o1)CCO3</smiles><smiles>[R]C(C)(C)[C@@H]1Cc2cc3ccc(=O)oc3cc2O1</smiles>

42 'S, $\mathrm{R}=\mathrm{H}$

52 ' $\mathrm{R}, \mathrm{R}=\mathrm{Glc}$

$62^{\prime} R, \mathrm{R}=\mathrm{H}$

$72^{\prime} R, \mathrm{R}=\mathrm{Glc}$<smiles>[R9]Oc1cc2oc(=O)ccc2c([R])c1[R2]</smiles>

$18 \mathrm{R}_{1}=\mathrm{H}, \mathrm{R}_{2}=\mathrm{H}, \mathrm{R}_{3}=\mathrm{Api}\left(1^{\prime \prime}-6^{\prime}\right) \mathrm{Glc}$

$19 \mathrm{R}_{1}=\mathrm{H}, \mathrm{R}_{2}=\xi \smile<, \mathrm{R}_{3}=\mathrm{H}$

$20 \mathrm{R}_{1}=\mathrm{H}, \mathrm{R}_{2}=\xi \underset{\mathrm{HO}}{\longrightarrow}, \mathrm{R}_{3}=\mathrm{H}$

$21 \mathrm{R}_{1}=\mathrm{H}, \mathrm{R}_{2}=\mathrm{H}, \mathrm{R}_{3}=$ Api $\left(1^{\prime \prime}-2^{\prime}\right) \mathrm{Glc}$

$22 \mathrm{R}_{1}=\mathrm{H}, \mathrm{R}_{2}=\mathrm{O}-\mathrm{Glc}, \mathrm{R}_{3}=\mathrm{CH}_{3}$

$23 \mathrm{R}_{1}=\xi \bigcirc \curlyvee, \mathrm{R}_{2}=\mathrm{H}, \mathrm{R}_{3}=\mathrm{CH}_{3}$

$24 \mathrm{R}_{1}=\mathrm{H}, \mathrm{R}_{2}=\underset{\mathrm{HO}}{\longrightarrow} \mathrm{OH}_{\mathrm{OH}} \mathrm{R}_{3}=\mathrm{Glc}$

$25 \mathrm{R}_{1}=\mathrm{H}, \mathrm{R}_{2}=$ HO $_{\mathrm{HOGlC}} \mathrm{R}_{3}=\mathrm{H}$

$26 \mathrm{R}_{1}=\mathrm{H}, \mathrm{R}_{2}=\underbrace{}_{\mathrm{O}} \underset{\mathrm{OH}}{\mathrm{C}} \mathrm{R}_{3}=\mathrm{H}$

$27 \mathrm{R}_{1}=\mathrm{H}, \mathrm{R}_{2}=\mathrm{H}, \mathrm{R}_{3}=\mathrm{Glc}$

$28 \mathrm{R}_{1}=\mathrm{H}, \mathrm{R}_{2}=\mathrm{H}, \mathrm{R}_{3}=\mathrm{H}$<smiles>O=c1cc[nH]c(=O)[nH]1</smiles>

36
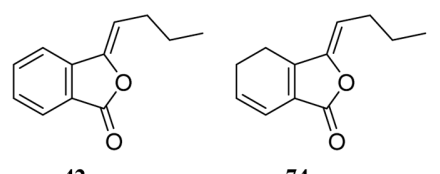

74

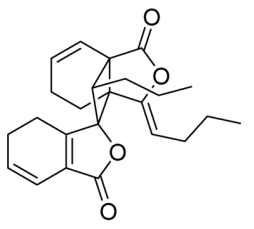

82

Fig. 1. Compounds from three Angelica species, Angelica gigas, A. sinensis and A. acutiloba. 


\section{Phytochemical constituents}

Dang-Gui has been shown to contain a variety of constituents including coumarins (1 - 28), flavonoids (29 35), and diverse essential oils (e.g., benzofuranone derivatives) (42, 74 and 82) (Fig. 1). The phytochemical components of Dang-Gui vary depending on the specific plant. Most domestic studies on Dang-Gui ingredients involved A. gigas because their roots are the primary source of this medicine in Korea.

The main components of $A$. gigas are decursin (10) and decursinol angelate (12), which are pyranocoumarins. Angelan is a pharmacologically active pectin polysaccharide isolated from A. gigas. ${ }^{6}$ The main component of A. acutiloba and $A$. sinensis is a benzofuranone, ligustilide (74), found in the essential oil fraction (Table 1). ${ }^{7}$ Most essential oils of the three Angelica species were identified by gas chromatography-mass spectrometry (GC-MS); however, further studies into the pharmacological activity and structure of butylidenephthalide (42), Z-ligustilide (74), and neodiligustilide (82) have been performed (Fig. 1).

\section{Pharmacological studies}

Although the pharmacological activities of these three Angelica species have been reported in Korean and

Table 1. Compounds from three Angelica species, Angelica gigas, A. sinensis and A. acutiloba (in Korean paper)

\begin{tabular}{|c|c|c|c|c|}
\hline \multirow{2}{*}{$\begin{array}{c}\text { Compound } \\
\text { no. }\end{array}$} & \multirow{2}{*}{ Compound name } & \multicolumn{3}{|c|}{ Species (ref.) } \\
\hline & & A. gigas & A. sinensis & A. acutiloba \\
\hline \multicolumn{5}{|c|}{ Furanocoumarins } \\
\hline 1 & Bergapten & roots $(8,9)$ & & \\
\hline 2 & Columbianetin- $O-\beta$-D-glucopyranoside & roots $(10)$ & & \\
\hline 3 & Isoimperatorin & roots (10), fruits (11) & & \\
\hline 4 & Marmesin & roots $(10)$ & & \\
\hline 5 & Marmesinin & roots $(10)$ & & \\
\hline 6 & Nodakenetin & $\operatorname{roots}(8,9,10)$ & & \\
\hline 7 & Nodakenin & roots $(8,9,10,12)$ & & \\
\hline 8 & Xanthotoxin & roots $(10)$ & & \\
\hline \multicolumn{5}{|c|}{ Pyranocoumarins } \\
\hline 9 & Decursidin & fruits (11) & & \\
\hline 10 & Decursin & $\operatorname{roots}(8,9,10,12,13)$ & & roots $(7)$ \\
\hline 11 & Decursinol & roots $(14)$ & & \\
\hline 12 & Decursinol angelate & $\operatorname{roots}(8,9,10,12,13)$ & & \\
\hline 13 & (2" $R, 3 " R$ )-Epoxyangeloyldecursinol & roots $(10)$ & & \\
\hline 14 & $(2 " S, 3 " S)$-Epoxyangeloyldecursinol & roots $(10)$ & & \\
\hline 15 & 4"-Hydroxydecursin & roots $(10)$ & & \\
\hline 16 & 4"-Hydroxytigloyldecursinol & roots $(10)$ & & \\
\hline 17 & Xanthyletin & roots $(10)$ & & \\
\hline \multicolumn{5}{|c|}{ Coumarins } \\
\hline 18 & Apiosylskimmin & roots $(10)$ & & \\
\hline 19 & Demethylsuberosine & roots $(10)$ & & \\
\hline 20 & $\begin{array}{l}\text { 7-Hydroxy-6-((2R)-hydroxy-3-methylbut-3- } \\
\text { nyl)coumarin }\end{array}$ & roots $(10)$ & & \\
\hline 21 & Isoapiosylskimmin & roots $(10)$ & & \\
\hline 22 & Magnolioside & roots $(10)$ & & \\
\hline 23 & 7-Methoxy-5-prenyloxycoumarin & roots $(10)$ & & \\
\hline 24 & (S)-Peucedanol-7-O- $\beta$-D-glucopyranoside & roots $(10)$ & & \\
\hline 25 & $(S)$-Peucedanol-3'-O- $\beta$-D-glucopyranoside & roots $(10)$ & & \\
\hline 26 & Peucedanone & roots $(10)$ & & \\
\hline 27 & Skimmin & roots $(10)$ & & \\
\hline 28 & Umbelliferone & roots $(10)$ & & \\
\hline
\end{tabular}


Table 1. continued

\begin{tabular}{|c|c|c|c|c|}
\hline \multirow{2}{*}{$\begin{array}{c}\text { Compounds } \\
\text { no. }\end{array}$} & \multirow{2}{*}{ Compound name } & \multicolumn{3}{|c|}{ Species (ref.) } \\
\hline & & A. gigas & A. sinensis & A. acutiloba \\
\hline \multicolumn{5}{|l|}{ Flavonoids } \\
\hline 29 & Avicularin & leaves (15) & & \\
\hline 30 & Diosmin & roots $(16)$ & & \\
\hline 31 & Isoquercetin & leaves (15) & & \\
\hline 32 & Kaempferol & leaves $(15)$ & & \\
\hline 33 & Luteolin & leaves (15) & & \\
\hline 34 & Luteolin-7- $O-\beta$-D-glucopyranoside & leaves (15) & & \\
\hline 35 & Quercetin & leaves (15) & & \\
\hline \multicolumn{5}{|c|}{ Nucleic acids } \\
\hline 36 & Uracil & $\operatorname{roots}(9)$ & & \\
\hline \multicolumn{5}{|c|}{ Essential oils and Miscellaneous } \\
\hline 37 & Aromadendrene & & & roots $(17)$ \\
\hline 38 & 1,4-Benzenedicaboxaldehyde & & & leaves (17) \\
\hline 39 & Borneol & & & leaves (17) \\
\hline 40 & Bornyl acetate & & & roots, leaves (17) \\
\hline 41 & Buthylphthalide & & & roots, leaves (17) \\
\hline 42 & Butylidenephthalide & & roots $(7)$ & roots $(7,17)$, leaves $(17)$ \\
\hline 43 & $\alpha$-Bisabolene epoxide & & & roots, leaves (17) \\
\hline 44 & $t$-Cadinol & & & leaves (17) \\
\hline 45 & Camphene & roots (18) & & roots, leaves (17) \\
\hline 46 & $\Delta$-3-Carene & roots (18) & & \\
\hline 47 & Carotol & & & roots (17) \\
\hline 48 & $\beta$-Caryophyllene & & & roots, leaves (17) \\
\hline 49 & Caryophyllene oxide & & & roots, leaves (17) \\
\hline 50 & $\alpha$-Cedrene & & & roots (17) \\
\hline 51 & Clovene & & & leaves (17) \\
\hline 52 & Cyclodecane & & & leaves (17) \\
\hline 53 & $p$-Cymene & roots $(18)$ & & \\
\hline 54 & Dibutylphthalate & & roots $(7)$ & roots $(7)$ \\
\hline 55 & $\begin{array}{l}\text { (11S,16R)-Dihydroxyoctadeca-9Z,17-dien-12,14- } \\
\text { diyn-1-yl acetate }\end{array}$ & & roots (19) & \\
\hline 56 & 4,4',5-Dimethyl- $\Delta$-2-cyclohexanone & roots (18) & & \\
\hline 57 & 2,6-Di-tert-butyl-methylphenol & roots $(18)$ & & \\
\hline 58 & $\Delta$-Elemene & roots (18) & & \\
\hline 59 & $\alpha$-Elemene & roots (18) & & \\
\hline 60 & $\beta$-Elemene & roots $(18)$ & & roots $(17)$ \\
\hline 61 & $\gamma$-Elemene & roots $(18)$ & & \\
\hline 62 & Elemol & roots (18) & & \\
\hline 63 & $\alpha$-Eudesmol & roots (18) & & \\
\hline 64 & $\beta$-Eudesmol & roots $(18)$ & & \\
\hline 65 & $(3 R, 8 S)$-Falcarindiol & & & roots $(17)$ \\
\hline 66 & $\beta$-Farnesene & roots (18) & & roots, leaves (17) \\
\hline 67 & Guaiol & roots $(18)$ & & \\
\hline 68 & $\alpha$-Guaiene & & & leaves (17) \\
\hline 69 & $\beta$-Guaiene & roots (18) & & \\
\hline 70 & $\Delta$-Guaiene & roots $(18)$ & & \\
\hline
\end{tabular}


Table 1. continued

\begin{tabular}{|c|c|c|c|c|}
\hline \multirow{2}{*}{$\begin{array}{c}\text { Compounds } \\
\text { no. }\end{array}$} & \multirow{2}{*}{ Compound name } & \multicolumn{3}{|c|}{ Species (ref.) } \\
\hline & & A. gigas & A. sinensis & A. acutiloba \\
\hline 71 & Isopropylidene bicyclo $(5,1,0)$ octane & roots (18) & & \\
\hline 72 & Khusimone & & & roots $(17)$ \\
\hline 73 & Lavandulyl acetate & & & leaves (17) \\
\hline 74 & $Z$-Ligustilide & & $\operatorname{roots}(7,19)$ & roots, leaves $(7,17)$ \\
\hline 75 & Limonene & roots $(18)$ & & roots, leaves (17) \\
\hline 76 & Linalool & & & roots, leaves (17) \\
\hline 77 & Linoleic acid & & & $\operatorname{roots}(7)$ \\
\hline 78 & 1-Methyl-4-(1-methylethyl)benzene & & & roots, leaves (17) \\
\hline 79 & $\alpha$-Muurolene & roots (18) & & \\
\hline 80 & Myrcene & roots $(18)$ & & roots, leaves (17) \\
\hline 81 & Neo-allo-ocimene & & & roots (17) \\
\hline 82 & Neodiligustilide & & roots (19) & \\
\hline 83 & Nerolidol & & & roots $(17)$ \\
\hline 84 & Myristicin & roots $(18)$ & & \\
\hline 85 & Myristicine & roots $(18)$ & & \\
\hline 86 & $n$-Nonane & roots (18) & & \\
\hline 87 & $n$-Undecane & roots $(18)$ & & \\
\hline 88 & cis-Ocimene & & & roots, leaves (17) \\
\hline 89 & Octadecadienoic acid methyl ester & & $\operatorname{roots}(7)$ & \\
\hline 90 & Octanal & & & roots $(17)$ \\
\hline 91 & Pentylbenzene & & & leaves (17) \\
\hline 92 & $\alpha$-Phellandrene & roots $(18)$ & & \\
\hline 93 & 1-Phenyl-1-pentanone & & & roots $(17)$ \\
\hline 94 & Phthalic anhydride & & & leaves (17) \\
\hline 95 & $\alpha$-Pinene & roots (18) & & leaves (17) \\
\hline 96 & $\beta$-Pinene & roots $(18)$ & & \\
\hline 97 & 4,5-Pinene oxide & roots $(18)$ & & \\
\hline 98 & Sabinene & & & roots $(17)$ \\
\hline 99 & $\alpha$-Terpinene & roots $(18)$ & & roots $(17)$ \\
\hline 100 & $\gamma$-Terpinene & roots $(18)$ & & roots, leaves (17) \\
\hline 101 & Terpinene-4-ol & & & roots, leaves (17) \\
\hline 102 & Terpinolene & roots $(18)$ & & \\
\hline 103 & Thymol & & & roots $(17)$ \\
\hline 104 & Thymyl methyl ether & & & roots $(17)$ \\
\hline 105 & Torreyol & roots (18) & & \\
\hline 106 & 4-Vinylguaiacol & roots (18) & & \\
\hline 107 & Vulgarol B & & & leaves (17) \\
\hline
\end{tabular}

international journals, the results in Korean journals are difficult to find outside of Korea. Domestic research has shown that these Angelica species have anti-inflammatory, antibacterial, antioxidant, antihyperlipidemic, hepatoprotective, and neuroprotective activities (Table 2).

In addition to studies on pharmacological activity, drug metabolism studies have also been conducted on the components of the three Angelica species. Woo et al. used mouse hexobarbital-induced hypnosis to investigate the effects of methanol extracts of A. gigas and A. acutiloba on drug metabolism and found that the furanocoumarin components of the extracts affected the drug-metabolizing enzymes. ${ }^{29}$ Shin et al. showed that decursin (10), a major component of $A$. gigas, inhibited the hepatic enzyme system. $^{30}$

To evaluate the efficacy of herbal medicines, Park et al. 
Table 2. Bioactivities of the three Angelica species, A. gigas, A. sinensis and A. acutiloba (in Korean paper)

\begin{tabular}{|c|c|c|c|c|c|}
\hline Therapeutic target & In vitro & In vivo & Other assay & Extracts/Active constituents & References \\
\hline \multirow[t]{6}{*}{ Anticancer } & L1210 & & & $65,74,82,89$ & 19 \\
\hline & K562 & & & 74,82 & 19 \\
\hline & Hela & & & $\begin{array}{l}\text { Essential oil fraction of } A \text {. acutiloba } \\
\text { (roots) } \\
\mathbf{4 2 , 7 4}\end{array}$ & 17 \\
\hline & MCF-7 & & & $\begin{array}{l}\text { Essential oil fraction of } A \text {. acutiloba } \\
\text { (roots) } \\
\mathbf{1 0 , 7 4}\end{array}$ & $\begin{array}{l}17 \\
21\end{array}$ \\
\hline & $\begin{array}{l}\text { U937, HL60, THP-1, } \\
\text { MOLT4, DU145, PC-3, } \\
\text { LNCaP }\end{array}$ & & & 10 & 21,22 \\
\hline & & mouse (ICR) & & 10,12 & 21,23 \\
\hline Antidiabetic & & $\begin{array}{l}\text { NOD mouse } \\
\text { (Non-Obese Diabetic } \\
\text { mouse model) }\end{array}$ & & Angelan & 24 \\
\hline Anti-inflammatory & & $\begin{array}{l}\text { rat (Sprague-Dawley), } \\
\text { mouse (ICR) }\end{array}$ & & $\begin{array}{l}\text { Water extract of } A \text {. gigas } \\
\text { Water extract of } A \text {. acutiloba }\end{array}$ & 25 \\
\hline Anti-melanogenic & $\mathrm{B} 16 \mathrm{~F} 1$ & & & 19 & 26 \\
\hline \multirow[t]{3}{*}{ Antimicrobial } & Bacillus subtilis & & & $\begin{array}{l}\text { Water extract of } A \text {. gigas } \\
\text { Water extract of } A \text {. acutiloba } \\
\mathbf{1 0}, \mathbf{1 2}\end{array}$ & 8,25 \\
\hline & Escherichia coli & & & $\begin{array}{l}\text { Water extract of } A \text {. gigas } \\
\text { Water extract of } A \text {. acutiloba } \\
\text { Essential oil fraction of } A \text {. acutiloba } \\
\text { (roots, leaves) }\end{array}$ & 17,25 \\
\hline & Helicobacter pylori & & & 10,12 & 21 \\
\hline Antimutagenic & & mouse (ICR) & & $\begin{array}{l}\text { Water extract of } A \text {. gigas } \\
\text { Water extract of } A \text {. acutiloba }\end{array}$ & 25 \\
\hline \multirow[t]{3}{*}{ Antioxidant } & & rat & & 10,12 & 27 \\
\hline & & & $\begin{array}{l}\text { DPPH radical } \\
\text { scavenging test }\end{array}$ & $\begin{array}{l}\text { Essential oil fraction of } A \text {. acutiloba } \\
\text { (roots, leaves) } \\
\mathbf{2 9}, \mathbf{3 1}, \mathbf{3 2}, \mathbf{3 3}, \mathbf{3 4}, \mathbf{3 5}, \mathbf{4 2}, \mathbf{7 4}\end{array}$ & $\begin{array}{l}17 \\
15\end{array}$ \\
\hline & & & $\begin{array}{l}\text { Reducing power } \\
\text { tests }\end{array}$ & $\begin{array}{l}\text { Essential oil fraction of } A \text {. acutiloba } \\
\text { (roots, leaves) } \\
\mathbf{4 2 , 7 4}\end{array}$ & 17 \\
\hline Chemopreventive & & mouse (ICR) & & $\begin{array}{l}\text { Aqua-acupuncture solution of } A \text {. gigas } \\
\text { (roots) }\end{array}$ & 28 \\
\hline Hepatoprotective & & mouse (ICR) & & $\begin{array}{l}\text { Water extract of } A \text {. gigas } \\
\text { Water extract of } A \text {. acutiloba }\end{array}$ & 25 \\
\hline & & rat & & $\begin{array}{l}\text { Water extract of } A \text {. gigas (roots) } \\
\text { Ethanol extract of } A \text {. gigas (roots) } \\
\text { Water extract of } A \text {. acutiloba (roots) } \\
\text { Ethanol extract of } A \text {. acutiloba (roots) } \\
\mathbf{1 0 , 1 2}\end{array}$ & $\begin{array}{l}31 \\
27\end{array}$ \\
\hline $\begin{array}{l}\text { Anti- } \\
\text { hyperlipidemia }\end{array}$ & & rat & & $\begin{array}{l}\text { Water extract of } A \text {. gigas (roots) } \\
\text { Ethanol extract of } A \text {. gigas (roots) } \\
\text { Water extract of } A \text {. acutiloba (roots) } \\
\text { Ethanol extract of } A \text {. acutiloba (roots) } \\
\mathbf{1 0 , 1 2}\end{array}$ & $\begin{array}{l}32 \\
21\end{array}$ \\
\hline $\begin{array}{l}\text { Immuno- } \\
\text { stimulating }\end{array}$ & $\begin{array}{l}\text { primary mouse spleen } \\
\text { cells }\end{array}$ & & & Crude polysaccharides of $A$. gigas (roots) & 33 \\
\hline \multirow[t]{2}{*}{ Neuroprotective } & $\begin{array}{l}\text { primary cultured rat } \\
\text { cortical cells }\end{array}$ & & & $2,3,4,5,7,10,11,13,14$ & 10 \\
\hline & & mouse & & 10,12 & 21 \\
\hline Anti-aggregatory & & rat (Sprague-Dawley) & & 10,12 & 12,21 \\
\hline Drug metabolism & & mouse & & $\begin{array}{l}95 \% \text { Methanol extract of } A . \text { acutiloba } \\
\text { (roots, fruits) } \\
\mathbf{1 0 , 1 2}\end{array}$ & $\begin{array}{l}29 \\
30 \\
20\end{array}$ \\
\hline
\end{tabular}


investigated drug interactions occurring during the administration of $A$. gigas extracts and other herbal medicines. In this study, they measured the concentration of decursinol (11) in blood, using decursin (10) and its metabolite decursinol (11) as indicator substances. ${ }^{20}$ This study found that oral administration of ether or methanol extracts of $A$. gigas resulted in higher concentrations of decursinol (11) in blood, as compared to treatment with decursin (10) alone. Coadministration of decursin (10) and Cnidii Rhizoma extracts increased the concentration of decursinol (11) in blood, while coadministration of decursin (10) and Bupleuri Radix extracts decreased the blood concentration of decursinol (11). However, coadministering Cnidii Rhizoma or Bupleuri Radix extracts with decursinol (11) increased the level of decursinol (11) in blood.

\section{Other studies}

As most herbal medicine is generally distributed after cutting and drying, there is a limit to distinguish the origins and producing area only by histological discrimination. To address this limitation, a clearer method for discrimination has been developed. To establish such a method, Cho et al. used non-destructive analytical techniques, including near-infrared spectroscopy, X-ray fluorescence spectrometry, and electronic nose, to compare and analyze $A$. gigas and $A$. sinensis. All three methods showed a discrimination rate of $90 \%$ or higher. Additionally, these methods are fast and simple and require no preprocessing. ${ }^{34}$

Kim et al. compared the concentration of coumarins between roots of $A$. gigas cultivated in Korea and China. They found that marmesin (4), nodakenin (7), decursin (10), and decursinol (11) were higher on average in Korean than Chinese roots. They successfully distinguished Korean and Chinese roots of A. gigas using multivariate analysis [Principal Component Analysis (PCA), Partial Least Squares Discriminant Analysis (PLS-DA)], based on decursin (10) and decursinol angelate (12). ${ }^{35}$

Decursin (10) and decursinol angelate (12), which are major components of $A$. gigas, are structural isomers with similar chemical properties, making the two compounds difficult to isolate and purify. To overcome this limitation, the conditions for analytical reverse-phase high-performance liquid chromatography (HPLC) of decursin (10) and decursinol angelate (12) were explored. ${ }^{36,37}$ The peaks were best separated using mobile phases composed of acetonitrile with sodium dodecyl sulfate and sodium dihydrogen phosphate, and acetonitrile with sodium lauryl sulfate and sodium phosphate. The optimum HPLC conditions were identified as a column temperature of 30 $35^{\circ} \mathrm{C}$, a flow rate of $1-1.2 \mathrm{ml} / \mathrm{min}$, with UV detection at 230 or $280 \mathrm{~nm}$.

An efficient, large-scale extraction process was proposed by comparing and analyzing the extraction efficiency of the components of A. gigas. ${ }^{36} \mathrm{Kang}$ et al. reported that the concentrations of decursin (10) and decursinol angelate (11) in $100 \%$ ethanol extracts were slightly higher than those in $50 \%$ ethanol extracts. However, there were greater differences in the extraction efficiency between ethanol extracts and deionized water extraction. As there was not a significant difference between $100 \%$ and $50 \%$ ethanol extracts, it was predicted that the extraction process using $50 \%$ ethanol would be more suitable for safety engineering in large-scale extractions.

In addition, Lee et al. proposed a method for massproducing decursinol (11), a starting material for the synthesis of various derivatives, including decursin (10) and decursinol angelate (12), by hydrolyzing A. gigas extracts. ${ }^{14}$ This study established a method for obtaining pure target compounds solely through recrystallization following hydrolysis, without complicated separation processes. They succeeded in producing a large amount of decursinol (11) from the root of A. gigas, and found that the highest yield of decursinol (11) was obtained using $\mathrm{NaOH}$. Additionally, they identified ether as the most effective solvent for hydrolysis.

\section{Conclusions}

Dang-Gui has been widely used as traditional medicine in Korea, China, and Japan and its botanical origins in the official compendia differ between the countries. The Korean pharmacopoeia defines the origin of Dang-Gui as A. gigas. In Korea, the most studied was carried out on $A$. gigas. Much less is known about the composition of $A$. sinensis than both $A$. gigas and $A$. acutiloba. Furthermore, there are no studies on the pharmacological activity of $A$. sinensis in Korea. Along with studies investigating the phytochemical components of the three Angelica species and the pharmacological activities of these components and extracts, this review showed four studies focused on classifying plant origin.

A variety of coumarins have been reported through studies investigating the components of Dang-Gui. Extracts and individual components of the three Angelica species were found to have anti-inflammatory, antibacterial, and antioxidant properties. Additionally, anticancer/cytotoxic, antihyperlipidemic, hypoglycemic, hepatoprotective, and neuroprotective activities of these extracts and 
individual compounds have been found to be effective in the prevention and treatment of lifestyle diseases such as diabetes, arteriosclerosis, and cancer. However, there are few studies on components other than coumarins, and studies relating to biological activity have focused primarily on decursin (10) and decursinol angelate (12), the main components of A. gigas and its extracts. Therefore, for a better understanding of Dang-Gui and its applications, it is required to expand the studies of various other compounds of this species and perform additional biological activity tests. In addition, continuous research on A. sinensis and A. acutiloba will improve the availability of Dang-gui for the modern medicinal uses.

\section{Acknowledgements}

This work was supported by the Brain Korea 21 Plus program.

\section{References}

(1) Anonymous. The Korean Pharmacopoeia $11^{\text {th }}$ Ed.; Ministry of Food and Drug Safety: Republic of Korea, 2014, p 1790.

(2) Anonymous. The Japanese Pharmacopoeia $16^{\text {th }}$ Ed.; The Ministry of Health Labor and Welfare: Japan, 2012, p 1866.

(3) Anonymous. Pharmacopoeia of the People's Republic of China; National Pharmacopoeia Commission of the People's Republic of China; China Medical Science Press: China, 2015, p 133.

(4) Park, J. H.; Lee, Y. J.; Keon, S. J. Kor. J. Pharmacogn. 2005, 36, 141-144.

(5) Ahn, M. J.; Bae, J. Y.; Park, J. H. Kor. J. Pharmacogn. 2011, 42, 103-106.

(6) Kim, H. J.; Piao, X. L.; Jang, Y. P. Nat. Prod. Sci. 2011, 17, 202-205.

(7) Kim, H. M.; Kang, J. S.; Park, S. K.; Lee, K.; Kim. J. Y.; Kim, Y. J.; Hong, J. T.; Kim, Y.; Han, S. B. Arch. Pharm. Res. 2008, 31, 1489-1496.

(8) Lee, S.; Shin, D. S.; Kim, J. S.; Oh, K. B.; Kang, S. S. Arch. Pharm. Res. 2003, 26, 449-452.

(9) Lee, S.; Kang, S. S.; Shin, K. H. Nat. Prod. Sci. 2002, 8, 58-61.

(10) Kang, S. Y.; Kim, Y. C. Arch. Pharm. Res. 2007, 30, 1368-1373.

(11) Yook, C. S.; Kim, C. W.; Ryu, K. S. Kor. J. Pharmacog. 1973, 4, 189-190.

(12) Lee, Y. Y.; Lee, S.; Jin, J. L.; Yun-Choi, H. S. Arch. Pharm. Res. 2003, 26, 723-726.

(13) Ryu, K. S.; Hong, N. D.; Kim, N. J.; Kong, Y. Y. Kor. J. Pharmacogn. 1990, 21, 64-68.

(14) Lee, J. H.; Choi, Y. S.; Kim, J. S.; Kim, J. H.; Jeong, H. G.; Kim, D. H.; Yun, M. Y.; Kim, J. S.; Cho, S. H.; Shen, G. N.; Kim, E. G.; Jin, W.
Y.; Song, G. Y. Yakhak Hoeji. 2006, 50, 172-176.

(15) Moon, H. I.; Ahn, K. T.; Lee, K. R.; Zee, O. P. Yakhak Hoeji. 2000, $44,119-127$.

(16) Lee, S.; Kang, S. S.; Shin, K. H. Nat. Prod. Sci. 2002, 8, 127-128.

(17) Roh, J.; Lim, H.; Shin, S. Nat. Prod. Sci. 2012, 18, 244-249.

(18) Chi, H. J.; Kim, H. S. Kor. J. Pharmacogn. 1988, 19, $239-247$.

(19) Chen, Q. C.; Lee, J. P.; Jin, W. Y.; Youn U. J.; Kim, H. J.; Lee, I. S.; Zhang, X. F.; Song, K. S.; Seong, Y. H.; Bae, K. H. Arch. Pharm. Res. 2007, 30, 565-569.

(20) Park, R. J.; Kim, N. J.; Lee, K. T.; Seo, S. H. Kor. J. Pharmacogn. 2001, 32, 72-78.

(21) Son, C. Y.; Baek, I. H.; Song, G. Y.; Kang J. S.; Kwon, K. I. Yakhak Hoeji. 2009, 53, 303-313.

(22) Kim, N. S.; Jeong, S. I.; Kim, J. S.; Oh, M. J.; Oh, C. H. Kor. J. Pharmacogn. 2016, 47, 197-203.

(23) Lee, S.; Lee, Y. S.; Jung, S. H.; Shin, K. H.; Kim, B. K.; Kang, S. S. Arch. Pharm. Res. 2003, 26, 727-730.

(24) Kim, H. M.; Kang, J. S.; Park, S. K.; Lee, K.; Kim, J. Y.; Kim, Y. J.; Hong, J. T.; Kim, Y.; Han, S. B. Arch. Pharm. Res. 2008, 31, 14891496.

(25) Kim, C. M.; Heo, M. Y.; Kim, H. P.; Sin, K. S.; Pachaly, P. Arch. Pharm. Res. 1991, 14, 87-92.

(26) Kim, Y. A.; Park, S. H.; Kim, B. Y.; Kim, A. H.; Park, B. J.; Kim, J. J. Kor. J. Pharmacogn. 2014, 45, 209-213.

(27) Lee, S.; Lee, Y. S.; Jung, S. H.; Shin, K. H.; Kim, B. K.; Kang, S. S. Nat. Prod. Sci. 2003, 9, 170-173.

(28) Kim, Y. K.; Cho, K. H.; Shon, Y. H.; Choi, H. K.; Kim, S. Y.; Lim, J. K.; Nam, K. S. Yakhak Hoeji. 2000, 44, 283-292.

(29) Woo, W. S.; Shin, K. H.; Ryu, K. S. Arch. Pharm. Res. 1980, 3, 7984.

(30) Shin, K. H.; Han, J. M.; Lee, I. R. Kor. J. Pharmacogn. 1996, 27, 323-327.

(31) Chung, M. H.; Oh, H. S.; Lim, J. H. Kor. J. Pharmacogn. 1998, 29, 402-412.

(32) Chung, M. H.; Lim, J. H.; Oh, H. S. Kor. J. Pharmacogn. 1998, 29, 300-311.

(33) Ahn, K. S.; Sim, W. S.; Kim, H. M.; Han, S. B.; Kim, I. H. Kor. J. Pharmacogn. 1996, 27, 254-261.

(34) Cho, C. H.; Kim, S. J.; Kim, H. J. Yakhak Hoeji. 2002, 46, 161167.

(35) Kim, J. R.; Lee, D. Y.; Sung, S. H.; Kim, J. Kor. J. Pharmacogn. 2013, 44, 332-335.

(36) Kang, Y. G.; Lee, J. H.; Chae, H. J.; Kim, D. H.; Lee, S.; Park, S. Y. Kor. J. Pharmacogn. 2003, 34, 201-205.

(37) Lee, J. P.; Chang, S. Y.; Park, S. Y. Nat. Prod. Sci. 2004, 10, 262267.

Received September 27, 2019 Revised October 12, 2019 Accepted December 13, 2019 